University of Nebraska - Lincoln

DigitalCommons@University of Nebraska - Lincoln

Public Health Resources

Public Health Resources

1953

The Ecology of Mosquito Borne Viruses

Carl M. Eklund

National Microbiological Institute

Follow this and additional works at: https://digitalcommons.unl.edu/publichealthresources

Part of the Public Health Commons

Eklund, Carl M., "The Ecology of Mosquito Borne Viruses" (1953). Public Health Resources. 102.

https://digitalcommons.unl.edu/publichealthresources/102

This Article is brought to you for free and open access by the Public Health Resources at DigitalCommons@University of Nebraska - Lincoln. It has been accepted for inclusion in Public Health Resources by an authorized administrator of DigitalCommons@University of Nebraska - Lincoln. 


\title{
THE ECOLOGY OF MOSQUITO BORNE VIRUSES ${ }^{1}$
}

\author{
By Carl M. EkLund \\ National Microbiological Institute, Department of Health, Education, and Welfare, \\ Rocky Mountain Laboratory, Hamilton, Montana
}

The ecology of a mosquito borne virus involves a consideration of the growth of the virus within the vertebrate and arthropod hosts, the reaction of these hosts to the presence of the virus, and the vertebrate-arthropod associations which are necessary for the dissemination and maintenance of the virus. Little is known of the physiological properties of a particular host and virus which permit multiplication of the virus. In this review stress will be laid upon studies which attempt to discover the mechanisms in nature which maintain these viruses. The first section will relate to the geographical distribution and time of occurrence of the viruses as indicated by clinical disease in human beings and domestic animals, antibody surveys among various animal species, and attempts at isolation of viruses from arthropods and other animals. Section two deals with transmission and viremia studies with suspected vectors and vertebrate hosts and virus cycles in the laboratory. Section three is concerned with field observations attempting to demonstrate that suspected vectors and their vertebrate hosts occur in sufficient numbers and are so associated that a virus cycle is possible. Section four deals with the problem of maintenance of virus during prolonged cold or dry periods. Section five pertains to serological relationships of interest from the standpoint of virus evolution. Some of the newly described viruses are described in section six.

The review is concerned primarily with the literature of the past five years and in case of yellow fever, with the past two years. Adequate reviews are available for previous literature $(1,2,3)$.

\section{Occurrence of Clinical Disease}

California virus.- Three possible cases of encephalitis were observed in California in the summer of 1945 by Hammon \& Reeves (4).

Western equine and St. Louis viruses.-California:-Lennette \& Longshore (5) reviewed 174 confirmed western equine encephalitis cases and 135 St. Louis encephalitis cases occurring in California from 1945 through 1950. These cases were limited essentially to the hot, irrigated agricultural sections of the Central and Imperial valleys. The greatest number of western equine encephalitis cases occurred during July; the greatest number of St. Louis encephalitis cases occurred during September. Although 20 per cent of the western equine encephalitis cases occurred in children under $1 \mathrm{yr}$,, only 1.5 per cent of the St. Louis encephalitis cases were found in this age group.

${ }^{1}$ The survey of the literature pertaining to this review was concluded in March, 1953. 
The greatest number of encephalitis cases was in 1950 with 157 , the smallest number was 1 in 1948. Although a summer with many western equine encephalitis cases usually showed an increase in the number of St. Louis encephalitis cases, the incidences of the two diseases did not bear any definite relationship to each other. The California State Department of Health (6) reported that from July 5 to November 3, 1952 there were 342 confirmed western equine, and 32 proven St. Louis encephali tis cases. The peak incidence of western equine encephalitis cases was in July, and the peak incidence of St. Louis encephalitis cases was in September.

Colorado:-Twenty-five cases of western encephalitis from northeastern Colorado were reported by Mulder (7) during the summer of 1949 .

Missouri:-Smith et al. (8) in 1948 reported that sporadic cases of St. Louis encephalitis had been encountered in St. Louis County every year since the 1937 outbreak.

Saskatchewan:-Laboratory experiences with western encephalitis cases in Saskatchewan from 1939 through 1951 were reviewed by Fulton \& Burton (9). In 1939 virus was isolated on two occasions from patients. From 1941 on, neutralization tests were performed on sera from suspected patients. In 1944 there were no positive sera, in the other years the number of positive sera varied from a low of 2 in 1946 to 96 in 1941 . There were 25 or more positive sera in 1941, 1942, 1948, and 1949. No serum with St. Louis neutralizing antibodies was found. Gareau (10) reported seeing epidemics of western encephalitis at Regina in 1938, 1939, 1941, and 1947.

Texas:- Four patients with western equine encephalitis were seen by Dravin et al. (11) at the veteran's hospital at Amarillo in the summer of 1949 , and also a St. Louis case from New Mexico.

Washington:-A summary of the incidence of acute summer encephalitis in the Yakima Valley from 1938 through 1949 was presented by Reeves et al. (12). In the years 1939 through 1942, the number of reported cases varied from 28 to 51 . Since then there has been little reported disease.

In addition to the above reports there were two which present difficulties. A case of western encephalitis was reported from Chicago by Saphir \& Milzer (13). This case occurred in May, 1948, and had no known exposure outside of the city. St. Louis virus was isolated by Sanders et al. (14) from the brain of a patient who died in Florida following a chronic illness resembling Guillain-Barres disease. A case of western equine encephalitis as early as May, and a chronic illness attributable to St. Louis virus are both most unusual.

Eastern equine encephalitis virus.-Louisiana:-Milner et al. (15) in August, 1946, isolated the eastern equine virus from a child living in southern Louisiana. Hauser (16) reported ten proven cases occurring during September and October 1947 in southern Louisiana.

Dominican Republic:-An outbreak involving 13 persons in the northern part of the Dominican Republic during late 1948 and early 1949 was reported by Eklund et al. (17). 
Venezuelan encephalitis virus.-Ecuador:-Levi-Castillo (18) observed a few cases in 1951 and stated that Venezuelan encephalitis has been a problem in the coastal plains.

Japanese encephalitis virus.-China:-Chao \& Chung (19) report that 229 cases of encephalitis were seen during the summer months at two Peking hospitals from 1942 through 1951, 28 prior to 1947 and 201 since. In addition, during the past few years acute encephalitis was reported from Canton and Taiwan in the south, Chungking and Changtu in the west, Shanghai and Nanking in the east, Tientsin, Peking, and Paoling in the north, Sian in the northwest, and Dairen and Mukden in the northeast of China.

Guam:- Hammon (20) reports an outbreak in Guam late in 1947 and early in 1948. This is the first epidemic reported in a tropical region.

Japan:-A small outbreak occurred in the inland sea area of Japan in 1947 (20). In 1948, according to Wyatt (21), a severe epidemic occurred throughout Japan, during which 8000 cases were reported.

Korea:-Epidemics have occurred in Korea in 1934, 1935, 1939, and 1949, according to Hullinghorst et al. (22). A few cases were observed in American troops in 1946. From the last week of August to the middle of October, 1949, 5548 cases were reported, and all provinces were affected with the exception of the Island of Cheju-Do. According to Lincoln \& Sivertson (23) and Dickerson et al. (24), approximately 300 cases occurred among American troops in Korea in the Pusan area from mid-July to midOctober, 1950.

Malaya:-The first case recognized in Malaya occurred near Kuala Lumpur in November, 1951, and was described by Paterson et al. (25). Subsequently, a case in a British soldier in Malaya, and three cases in Singapore in children have been reported (26).

Manchuria:-Mitamura et al. (27) reported the occurrence of the disease in southern Manchuria in natives in 1945, 1946, and 1947, and in Soviet troops in 1946 and 1947.

Okinawa:-Tigerett \& Hammon (28) summarized available data. A history of 68 cases in 1933 was obtained. In each year from 1945 to 1949 inclusive, cases were recognized. The smallest number of reported cases was 32 in 1946, and the largest number was 196 in 1947. Cases occurred from June to September.

Philippines:- In May, June, and July 1946, Salafranca \& Espiritu (29) saw 5 patients with central nervous system symptoms and rising antibody titers. Some of the cases appear to have been atypical.

Murray Valley encephalitis virus.-Victoria:-Anderson (30) during the first 15 weeks of 1951, saw 40 cases of acute encephalitis in the Murray Valley district of northern Victoria and the immediately adjacent area of southern New South Wales. It resembled the acute encephalitis which occurred during late summer in western and central New South Wales and in parts of Victoria and Queensland during 1917 and 1918. In 1951 a small number of cases also occurred in South Australia north of Adelaide, and 
were studied by Miles et al. (31). Derrick (32) has pointed out that acute encephalitis in Australia has not been limited to the Darling Basin. In 1917 the epidemic extende: $d$ as far as Brisbane and Townsville in Queensland, in 1922 there was an epidemic in South and Central Queensland which did not extend into New South Wales, and in 1925 cases occurred at Townsville as well as New South Wales. Young children at Townsville were affected during 1942. In 1951 cases occurred in several parts of Queensland.

Rift Valley fever virus.-South Africa:-Rift Valley fever was first recognized in the Union of South Africa in the autumn of 1951. The disease was observed in the western portion of the Orange Free State, the Southern Transvaal, and the Northwestern Cape Provinces $(33,34,35,36)$.

Yellow fever virus.-Panama:-Elton (37) reports that sylvan yellow fever appeared east of the Canal near Pecora during November and December, 1948. Cases were then recognized in August and September, 1949, January 1950, and April 1951, the outbreak proceeding toward the Atlantic Coast and the West. In June 1951, the first case was recognized in eastern Costa Rica near the Panamanian border. From late in July until early October there was a severe outbreak in the northeastern part of Costa Rica. In October 1951, yellow fever appeared on the Pacific coast of Costa Rica. In January 1952, a case occurred near the border of western Panama, and in February 1952, a case was recognized just over the border of Panama. In July and August 1952, cases appeared in eastern Nicaragua (38). No case of yellow fever had been recognized in Central America since 1924.

Periodicity in occurrence of yellow fever.-Kumm (39) reviewed the reported occurrence of yellow fever during the first 50 years of this century. Most reported cases were from the Americas. The period of time between successive peaks of high prevalence varied from 2 to 13 years with a median of 6 years. Data from the viscerotomy services of Brazil, Bolivia, and Colombia showed the same periodicity with peaks of high prevalence at 5 to 9 years with a median of $6 \frac{1}{2}$ years.

\section{Animal Infections}

Eastern equine virus.-United States:-There were two severe localized outbreaks of the eastern type in the past five years among horses; one in Louisiana in 1947, and one in Louisiana and Arkansas in $1949(40,41)$. Over 14,000 horses and mules were reported to have been sick in Louisiana in 1947 , and 1525 in 1949 , with an undetermined amount of disease among wild horses.

From August 24 to early October 1951, epizootics caused by the eastern virus occurred among pheasants on three breeding farms in Connecticut (42). In New Jersey outbreaks in pheasants were noted once in 1948, and five times in 1951. In Pennsylvania there was one outbreak in 1951 near the New Jersey border. Onset of these epizootics varied from late July to late October (43).

Dominican Republic:-The small outbreak of the eastern type of human 
encephalitis in 1948 and 1949 was preceded and accompanied by a severe epizootic among horses and donkeys (17).

Philippines:- Livesay (44) reported the isolation of the eastern equine virus from a sick monkey in Manila during 1947, thus providing the first evidence that eastern virus is present outside of the Western Hemisphere.

Venezuelan encephalitis virus.-Ecuador:-The disease is a problem among horses and mules of the coastal plains of Ecuador (38).

Japanese encephalitis virus. - China:- According to Okubi et al. (45), epizootics were observed among horses in north China during the summers of 1940 and 1945.

Japan:-During the summer of 1947, Burns \& Matumoto (46) reported 1209 horses affected, the most severe epizootic since 1935 and 1936. Every island was affected except Hokkaido. In southern Japan most cases occurred during July and August, in northern Japan during September and October.

During the summers of 1947 and 1948 a large number of pregnancies in swine termined in still births and sick piglets, from the latter of which virus was isolated. There had been a similar disease among swine during the 1935 epidemic $(47,48,49)$.

Malaya:-Paterson et al. (25) reported a small outbreak among race horses at Singapore in late July and early August, 1951.

Rift Valley fever virus. - South Africa:-In addition to illness of sheep and cattle, abortion was noted in wild springbuck and blesbuck in the epizootic in the Union of South Africa $(33,34)$. Much disease in human beings appeared to be a contact infection from autopsies on dead animals.

Human and animal disease is of value as an indicator of virus presence mainly during periods of severe epidemics and epizootics, and even then because of the frequency of subclinical infection it is a poor indicator of the extent of dissemination of virus. During interepidemic and interepizootic periods, antibody surveys and isolation of virus from invertebrate hosts, and occasionally from vertebrate hosts, must be used to detect virus. With most of these viruses, and possibly with all, involvement of man or his domestic animals appears to be a fortuitous event, and search for more fundamental cycles necessary for the existence of the virus must be pursued among other species. Human and animal disease, however, is valuable in demonstrating climatic conditions and geographical areas favorable for the existence of the virus. Also the periodicity in the appearance of such disease must reflect some fundamental variations in the mechanisms supporting the growth of the virus.

\section{Antibody Surveys: Sera of Human Beings}

California virus.-In Kern County General Hospital from 1944 to 1949, 11.1 per cent of 188 patient sera had neutralizing antibodies. Since there was no evidence that any patient had disease caused by this virus, 11 per cent presumably represents the incidence of antibodies in this county. In 1947 and 1948, the California Health Department Laboratory found 7.8 per cent 
of 292 sera with neutralizing antibodies. Of 157 sera from the hot valley areas, 10 per cent had antibodies; of 135 sera from all other parts of the state, 5.2 per cent had antibodies. A small number of sera from Washington, Colorado, North Dakota, Kansas, and Tokyo had no neutralizing antibodies (4).

Eastern equine virus.-Louisiana:-In 1947, 4 of 22 sera from members of families of patients had antibodies, but antibodies were not present in the sera from 23 neighbors (50). In the Dominican Republic in 1949, an incidence of 13 per cent of neutralizing antibodies was found at Monte Christi on the coast. Inland, the incidence of antibodies dropped until 35 kilometers from the coast no antibodies were found (17).

Japanese encephalitis virus.-Japan:-Bowell et al. (51) in 1946 obtained sera from people living in four areas of Japan, selected for a north-south representation. Little human disease had been recognized since a severe outbreak in 1939. At Sapparo, in the north, 4 per cent of 233 sera had neutralizing antibodies. At Tokyo and vicinity there were few persons with antibodies under the age of eight. Antibody incidence increased from 51 per cent in the 10 to 14 age group to 92 per cent in the 20 to 39 age group. Above this it was 100 per cent. At Okayama no children under five had antibodies. The incidence increased from 12 per cent in the 5 to 9 age group to 60 per cent in the 15 to 19 age group and reached 98 per cent in the 60-and-over age group. At Kumamoto in the south, the incidence was 11.5 per cent in the age group below 9 . It increased to 33 per cent in the 15 to 19 age group, and to 78 per cent at 60 and over.

China:-Mitamura et al. (27) reported an incidence of 61 per cent of neutralizing antibodies in 1941 in central China and 44 per cent in French Indo-China.

Korea:-A survey in 1946 by Deuel et al. (52) at Seoul and vicinity showed an incidence of 16 per cent in the 1 to 4 age group, a gradual rise to 80 per cent in the 20 to 39 age group, and a slightly greater per cent in older age groups. At Kunson and vicinity the incidence in the 1 to 4 age group was 63 per cent, in the 5 to 9 age group, 85 per cent, and 100 per cent in the age group 20 or over.

Malaya:-In sera collected in Malaya over the period of 1948-50, neutralizing antibodies were found in 23 of 27 native Malayans, and in 9 of 23 others (25).

Manchuria:-Mitamura et al. (27) reported a 30 per cent incidence of neutralizing antibodies at Kirin in 1936 and no antibodies at Harbin in 1942.

Okinawa:-Sera obtained in December 1946 from two villages on the west coast where encephalitis had occurred in 1945 showed 27 per cent neutralizing antibodies in the 3 months to 4 year group, 78 per cent in the 10 to 14 age group, and 90 per cent or greater in the age groups over 15 (52).

Philippines:-In 1949 Salafranca and Espiritu (29) reported that 7 of 
21 adult Filipinos had sera with neutralizing antibodies. Mitamura et al. (27) in 1938 found 1 of 96 people in Manila with antibodies.

Sumatra:-Hammon quotes Kitaoka as having found antibodies in people of Sumatra (20).

Java:-Mitamura et al. (27) in 1939 found 2 of 91 people with antibodies.

Murray Valley encephalitis virus.-Victoria:-In 1951 in northwestern Victoria, 20.4 per cent of people over, and 7.5 per cent under 15 years of age had complement-fixing antibodies. In northeastern Victoria approximately 4.5 per cent of people of all ages had such antibodies. In the rest of Victoria, north of the Divide 3.1 per cent and south of the Divide approximately 0.75 per cent, had complement-fixing antibodies. Of sera from Queensland, 24 of 119 had antibodies, from New South Wales 5 of 135, from Western Australia 1 of 55, from New Guinea 13 of 58, from Tasmania 1 of 85, and from New Zealand none of 9 sera had antibodies (53). Of sera obtained early in 1952 none of 85 sera from northwestern Victoria, 1 of 369 from northern Victoria, 3 of 287 from New South Wales, and 2 of 361 from Queensland showed complement-fixing antibodies (54).

Miles \& Howes (55) found that 25 of 284 sera from South Australia and the Northern Territory contained neutralizing antibodies, and 12 contained complement-fixing antibodies.

St. Louis encephalitis virus.-Missouri:-Surveys in St. Louis County, Missouri, in 1943 and 1944, showed neutralizing antibodies in the sera of 37 per cent of 97 people living in St. Louis through 1933 and 1937 and in 5.3 per cent of 56 people who had come into the area from the east since 1937 (8).

Rift Valley fever virus.- Smithburn et al. (56) in Uganda found neutralizing antibodies in 3 of 101 sera from adults, in none of 65 sera from children.

\section{Antibody Surveys: Sera of Animals Other than Man}

California virus.-California:- In Kern County, California, sera from 3 of 21 cottontail rabbits, 4 of 22 jackrabbits, 11 of 57 ground squirrels, all of 8 horses, and all of 3 cows contained neutralizing antibodies. None of 11 chicken sera had antibodies. A small number of sera from northern California and the State of Washington had no antibodies (4).

Eastern equine virus.-C United States:- In 1947 in Louisiana, sera of 9 of 14 horses, 1 of 3 dogs, and 2 of 105 chickens had neutralizing antibodies. No antibodies were found in sera from 1 pig, 8 ducks, 8 geese, 3 turkeys, and 35 pigeons (49). In 1947 in Tennessee, 2 of 31 chickens and 1 of 7 cows had antibodies, whereas 4 horses and 1 dog had no antibodies (57).

Philippines:-Mace et al. (58) found that 26 of 86 sera from known unvaccinated horses in the Manila area had neutralizing antibodies. N one of 14 chicken sera had antibodies.

Western equine virus.-Colorado:- In Weld County in 1950, 2.6 per cent of 191 sera from small mammals had antibodies (59). In 1949, 28 per cent of 89 wild and domestic bird sera contained antibodies (60). 
Kansas and Missouri:-11.6 per cent of 112 wild bird sera collected in 1949 contained antibodies (60).

Louisiana:-In 1947 the sera of 1 of 3 dogs and 19 of 88 chickens had neutralizing antibodies. The sera from 16 horses, 1 pig, 8 ducks, 8 geese, 3 turkeys, and 30 pigeons had no antibodies (57).

Washington:-Of wild and domestic bird sera collected in the Yakima Valley in 1949, 1 per cent of 302 had antibodies. Comparing the same species, it was found that 24.5 per cent of the sera was positive in 1941 as compared with 1.1 per cent in 1949 (12).

St. Louis virus.-Colorado:-In Weld County in 1949, none of 68 wild and domestic bird sera contained neutralizing antibodies (60). In 1950, 1 of 109 sera from small wild mammals had neutralizing antibodies (59).

Kansas and Missouri:- None of 68 wild bird sera collected in Kansas and Missouri in 1949 had St. Louis an tibodies (60). Surveys carried out by Smith and associates (8) in St. Louis County, Missouri, in 1943 and 1944 showed an incidence of 11 to 33 per cent of antibodies in 5 chicken flocks.

Washington:-Of wild and domestic bird sera collected in the Yakima Valley in 1949, 7.7 per cent had neutralizing antibodies. Comparing sera from the same species, 25.8 per cent were positive in 1941 and 9.8 per cent in 1949 (12).

Japanese encephalitis virus.-Japan:-In 1946 at Sapparo there were neutralizing antibodies in the sera of 12 of 30 horses, but in none of 19 cows, 20 swine, and of 5 chickens. At Tokyo there were antibodies in the sera of 14 of 22 horses, 2 of 16 cows, 7 of 20 swine, 2 of 20 goats, and none of 18 chickens. At Okayama there were antibodies in the sera of 9 of 20 cows, 8 of 16 goats, but none of 20 horses and of 15 chickens. At Kumamoto, there were antibodies in the sera of 13 of 20 horses, 3 of 10 swine, and none of 20 cows (51). At Okayama during the summer of 1947 , Burns \& Matumoto (61) observed 14 horses, initially without antibodies, and found that all acquired neutralizing and complement-fixing antibodies by the end of the summer. In addition, they observed that 5 of 6 cows and 1 of 8 sheep acquired neutralizing antibodies. Various species of animals observed at Yokohama, Saitama Prefecture, and Tokyo did not acquire antibodies. Of 56 wild bird sera collected by Hammon et al. (62) in 1949, 7 had neutralizing antibodies. In a later collection, 21 per cent of 214 had antibodies. Large water birds such as herons, egrets, and cormorants, together with magpies, had the highest percentage of positive sera.

Korea:-In 1946 in the vicinity of Seoul all of 20 horse sera, 14 of 20 cow sera, all of 20 swine sera, and none of 11 chicken sera had neutralizing antibodies. Of sera collected at Kunsan and vicinity all of 9 horse sera, 16 of 17 cow sera, all of 10 swine sera, and none of 12 chicken sera had antibodies (52). Following the 1949 epidemic, neutralizing antibodies were found in all of 30 horses sera, all of 17 swine sera, all of 14 dog sera, 20 of 30 cattle sera, 12 of 25 sheep sera, 1 of 5 chicken sera, and none of 3 goat sera (22). 
Okinawa:-In 1945 and 1946, 77 of 82 horses sera, 16 of 22 cow sera, 18 of 42 goat sera, 19 of 23 swine sera, 1 of 2 thrush sera, and none of 24 chicken, 4 duck, and 15 crow sera had neutralizing antibodies (28).

Malaya:-Indigenous Malayan ponies from various areas possess neutralizing antibodies (25).

Philippines:-Neutralizing antibodies were found in the sera of 13 of 29 cattle, 10 of 11 carabaos, 2 of 8 goats, and 21 of 23 horses (29). Mitamura et al. (27) report that in 194325 of 44 horses and 4 of 38 cattle had antibodies.

Other areas:-Antibodies have been found in horse sera from Sumatra, Java, Burma, Formosa, and South China (27).

Murray Valley encephalitis virus.-In 1951, Anderson et al. (53) found complement-fixing antibodies in the sera of 37 of 38 horses in northern Victoria, of 4 of 191 in Victoria south of the Divide, of 2 of 7 in Queensland, of 11 of 110 in New South Wales, of none of 40 in Western Australia, and of 0 of 3 in Tasmania. Sera of 5 of 9 foxes and 2 of 3 opossums from New South Wales had complement-fixing antibodies. In northwestern Victoria 15 of 20 species of water birds and 7 of 20 species of land birds were found to have neutralizing antibodies.

Miles \& Howes (55) found that 29 of 86 sera from horses in South Australia and the Northern Territory had neutralizing antibodies, 13 also had complement-fixing antibodies, and one had complement-fixing antibodies alone. Sera collected in April 1952 from 50 domestic fowl and 6 young cormorants in northwestern Victoria did not have neutralizing antibodies according to Anderson (54).

Rift Valley fever virus.-Smithburn et al. (56) found no neutralizing antibodies in the sera from 72 monkeys, 1 buffalo, and 1 waterbuck in Bwamba, Uganda.

Yellow fever virus.-Clark (63), from the Gorgas Memorial Laboratory, during 1949 and 1950 collected sera chiefly from monkeys but a few from other species in Panama; 104 of 201 sera collected east of the Canal and 68 of 224 collected west of the Canal had neutralizing antibodies. Early in 1951 monkey sera were collected in southern Mexico in the State of Chiapas. Three of 43 had neutralizing antibodies. Rodaniche (64) from the same laboratory, using sera from live monkeys purchased from trappers from 1949 through 1951, found that none of the sera from 44 monkeys captured west of the Canal had antibodies although 12 of 157 sera from monkeys east of the Canal had antibodies distributed as follows: 6 of 42 in 1949, 2 of 36 in 1950 and 4 of 79 in 1951. A pygmy anteater captured in the Canal Zone during 1951 and 2 agoutis captured in the Province of Darien in 1951 had transitory neutralizing antibodies. In part, according to Rodaniche, the difference between these figures and those of Clark may be explained by the number of juvenile animals in the last series.

Africa:-Dick (65), working in Uganda, found 1 of 9 hyraxes, 1 of 3 Red River hogs, and 2 of 15 mongooses with antibodies. Haddow et al. (66) in Uganda between 1942 and 1947 found 43.7 per cent of 1025 primate sera 
to have antibodies. The incidence varied from 4.1 per cent in monkeys under six months of age to 67.5 per cent in adults of three years or older. The highest incidence was found in lowland rain forest. Two adjacent similar areas might differ widely with respect to the number of immune monkeys. Rapid appearance of antibodies was seen in Bukasa Island in Lake Victoria, where, in April 1943, 1 of 33 monkeys had antibodies, while in December 1943,32 of 36 had antibodies. Of monkeys exclusively arboreal, 60.5 per cent had antibodies, of those mainly terrestrial, antibodies were present in $\mathbf{3 5 . 2}$ per cent. In Kenya, Haddow (67) found galagos superior to monkeys as an indicator of the presence of virus; 14 of 81 galagos had antibodies as against 5 of 271 monkeys.

Antibody surveys properly controlled for specificity are very sensitive indicators of virus presence. They usually show that virus is also present during interepidemic and interepizootic periods. They point to animal species which must be considered in the maintenance of virus. When sera are obtained from representative age groups the years of marked dissemination of virus can be determined; this may vary for different species.

\section{IsOlation OF Virus From MOSQUitoes}

California virus.-Virus was isolated in Kern County, California, from two lots of Aedes dorsalis, collected in June 1943 and June 1944, and from one lot of Culex tarsalis collected during July 1944. A similar virus has been isolated from $A$. trivittatus collected in North Dakota (4).

Eastern equine virus. - Chamberlain et al. (68) isolated virus from Culiseta melanura collected August 17, 1950, in southern Louisiana. Howitt et al. (69) isolated virus from Mansonia perturbans collected in Georgia in the summer of 1948.

Western equine virus. - In Weld County, Colorado, in the summer of 1950, virus was isolated on two occasions from $4492 \mathrm{~A}$. dorsalis. No virus was isolated from 1141 C. tarsalis (70). Virus was not isolated from 3277 C. tarsalis collected in the Yakima Valley in the summer of 1949, in contrast to the findings from 1941 through 1944 when virus was frequently isolated (12).

Japanese encephalitis virus.-China:-The isolation of virus from $C$. pipiens was reported (19).

Japan:-Hammon and associates $(28,71)$ reported the isolation of virus from nine lots of $C$. tritaeniorhynchus collected in Okayama before the onset of the 1948 epidemic and in 1949 from two lots of C. tritaeniorhynchus collected in Tokyo before the appearance of cases. Mitamura et al. $(72,73)$ isolated virus in 1942 at Okayama from mice bitten by three lots of $C$. tritaeniorhynchus and one lot of $C$. tritaeniorhynchus containing two unidentified mosquitoes. In only one instance was there illness in the initial mouse. Isolations in previous years are summarized without giving mosquito species or passage number in mice. In the summer of 1938 virus was isolated from 7 mice exposed to mosquito bites, in the summer of 1939 from 13 mice, in 
the summer of 1940 from 2 mice, and in 1941 no isolations were made. Sabin (74) was unable to isolate any virus from 2915 C. tritaeniorhynchus, 1410 C. pipiens, 1490 Anopheles hyrcanus sinensis, and 506 Armigeres obturbans collected in various parts of Japan in the summers of 1946 and 1947.

Okinawa:-Mosquito collections were made by various American workers from 1945 through 1948. No virus was isolated (28).

Guam:-No virus was isolated from 20,361 mosquitoes collected from February to March 1948, and from November to January 1949. A. pandani and $C$. quinquefasciatus were the predominant mosquitoes (75).

Rift Valley fever virus.-Smithburn et al. (56) isolated virus from two pools of 2307 and 2326 mosquitoes of the A.tarsalis complex, three pools of Eretmapodites species containing 441, 942, and 347 mosquitoes, respectively, and one pool of $60 \mathrm{~A}$. de boeri subspecies de-Meilloni collected between April 18 and May 27, 1944, in Bwamba, Uganda. Only the Eretmapodites group appeared to contain large amounts of virus.

\section{IsOlation OF Virus from Mites}

Eastern equine virus.-Virus was isolated from approximately $300 \mathrm{Der}$ manyssus gallinae collected in Tennessee in August 1947 (57).

Western equine virus.-Hammon and associates (76) state that from wild bird mites an isolation is made for approximately every 11,000 mites examined, and isolations do not precede those made from mosquitoes. Virus was isolated by Miles et al. (77) from about 500 D. americanum collected in an English sparrow's nest in Weld County, Colorado, July 18, 1950. They examined 78 lots of about 500 mites each. There were 35 lots of D. americanum, 23 D. gallinae, 5 Liponyssus sylviarum, and 15 of various mixtures of these species.

\section{Isolation of Virus from Animals Without Apparent Disease}

Eastern equine virus.-Virus was isolated by Kissling et al. (78) from the blood of a purple grackle shot in southern Louisiana, June 19, 1950.

Western equine virus.-Sooter and associates (79) collected 1491 blood specimens from 20 species of nestling birds in Weld County, Colorado, in 1950, 151 in June, 454 in July, 501 in August, and 257 in September. Virus was isolated from 2 of 55 blood specimens from red-winged blackbirds and from 1 of 224 from magpies. These specimens were collected between June 26 and June 30 .

\section{Laboratory Studies on Virus Transmission}

Isolation of virus from a mosquito or mite species must be confirmed by transmission studies before it can be concluded that they play a role in a virus cycle. Demonstration of antibodies in, or isolation of virus from the blood of an animal must be confirmed by the demonstration of viremia of sufficient extent to infect a mosquito or mite.

Studies with mosquitoes.-California virus:-Reeves \& Hammon (80) in 
limited studies had a successful transmission with $A$. dorsalis after feeding on a mouse brain virus suspension diluted 1 to 1000 .

Eastern equine encephalitis virus:-Chamberlain has secured transmission with Psorophora ferox, $P$. confinnis, $P$. ciliata, and $P$. howardii (42).

Venezuelan encephalitis virus:-Levi-Castillo (18) reports transmission by $C$. quinquefasciatus and $A$. taeniorhynchus.

Japanese encephalitic virus:-Chao \& Chung (19) state that Huang found $A$. chemulpoensis to transmit the virus readily to mice but $C$. pipiens did not. Hammon and associates (81) transmitted virus to mice by the bite of C. tritaeniorhynchus and C. pipiens. Hurlbut \& Thomas (82) reported transmission by $C$. annulirostris and $C$. quinquefasciatus to mice. According to Kitaoka et al. (83), seven species. C. tritaeniorhynchus, $C$. pipiens, Aedes japonicus, A. togoi, A. albopictus, Armigeres obturbans, and Anopheles hyrcanus sinensis can transmit the virus to mice. Tigertt \& Hammon (28) state that American workers in 1949 confirmed transmission by $A$. togoi and $A$. albopictus.

Rift Valley fever virus:-Smithburn et al. (84) showed that two lots predominately Eretmapodites chrysogaster after feeding on infected mice or lambs, could transmit virus to these species of animals.

Studies with mites.--Reeves (85) was unable to repeat the work on mite transmission of St. Louis virus by Smith et al. (86) and also had negative results with the western and eastern equine viruses. He states that Chamberlain also had negative results.

\section{Viremia in Experinental Animals}

California virus.-Virus was present in undiluted blood of ground squirrels 48 to $60 \mathrm{hr}$. after subcutaneous inoculation of $100 \mathrm{LD}_{50}$ of virus (87).

Western equine encephalitis virus. - Hammon and associates (76) found, after inoculation of small amounts of virus subcutaneously, that English sparrows had viremia from the first to the fourth day after inoculation with a maximum titer of $10^{4}$ on the first day, that the house finch had viremia as long as the nin th day with a titer of $10^{4}$ during the second and third days, that the tricolored red-winged blackbirds had a titer of $10^{6}$ on the second day and a small amount of virus as long as the tenth day, and that the white crowned sparrow had a titer of $10^{5}$ on the second day and some virus as long as the eleventh day.

St. Louis encephalitis virus. - The same species of birds had viremia of about equal duration but of much lower titer except in white crowned sparrows which had a titer of $10^{4.5}$ on the third day. On the third day, the house finch had a titer of $10^{2.3}$ and the tri-colored red-winged blackbird a titer of 101.3. In the English sparrow virus was detected in undiluted blood (76).

Japanese encephalitis virus. - A low grade viremia was found in chickens and English sparrows. In house finches virus was found from the first to the seventh day, with virus in the $10^{-2}$ dilution on the second and third days. 
In the tricolored red-winged blackbird virus was found from the first day to the sixth day and in the $10^{-3}$ dilution on the third day (62).

Murray Valley encephalitis virus.-Miles (88), using large amounts of virus intracerebrally, found virus in undiluted blood for a few days in young chickens, pigeons, and domestic ducks, and in silver gulls up to eight days.

Rift Valley fever virus.-Smithburn et al. $(84,89)$ in two lambs found virus on the second, third, and fourth days following bites of infected mosquitoes. The maximum amount of virus found was $10^{4.7} \mathrm{LD}_{50}$ per ml. on the third day. In accidental infections in laboratory personnel, over $10^{6} \mathrm{LD}_{60}$ per $\mathrm{ml}$. was found on the first and second days of illness. Virus was found from the first through the fifth day of illness.

Yellow fever virus. - In hedgehogs obtained in Kenya, Dick (65) found a titer of $10^{4.5}$ on the fourth day following subcutaneous inoculation. Three of six genets tested had viremia. The maximum amount of virus found in one animal was $10^{2.4}$ on the sixth day.

Virus cycles.-To support laboratory and field observations pointing to certain vectors and their hosts as of importance in maintaining a virus, attempts are occasionally made to set up such cycles in the laboratory. Ross \& Gillett (90) maintained yellow fever virus through three complete cycles using Grivet monkeys and $A$. africanus. Hurlbut \& Thomas (91) carried Japanese encephalitis virus through one complete cycle using $C$. quinquefasciatus and 3 to 12-day-old mice.

\section{Ecological Studies of Suspected Virus Cycles}

Western equine virus.-Jenkins (92) collected data on the distribution of C. tarsalis and showed that its distribution fits the known distribution of the equine disease quite well.

Japanese encephalitis virus. - China:-At Peking the breeding season of $A$. chemulpoensis is July and August and fits the occurrence of human disease better than that of $C$. pipiens which extends from early May to late October.

Japan:-Mitamura et al. $(72,73)$ collected mosquitoes within buildings at the Okayama Medical School throughout 1941 and 1942. The peak population of $C$. tritaeniorhynchus appeared to fit the occurrence of encephalitis best. In 1941 C. tritaeniorhynchus had its peak population early in August when it comprised one-third of all mosquitoes collected. Similar conditions were present in 1939 and 1940. In 1942 there was a sharp peak in the middle of July, and during late July and early August it comprised 92 per cent of mosquitoes collected. A similar condition was found in 1938.

During the summer of 1946 in miscellaneous collections Sasa \& Sabin (93) found $C$. tritaeniorhynchus dominant in Okayama City with $C$. pipiens and $A$ nopheles hyrcanus sinensis present. In mountain districts where cases had been reported $C$. vishnui was dominant with $A$. hyrcanus sinensis present. $C$. tritaeniorhynchus was absent, and $C$. pipiens practically so. In a 
lowland coastal area $C$. tritaeniorhynchus was dominant and Mansonia uniformis well represented. C. tritaeniorhynchus fed predominantly on domestic mammals, while $C$. pipiens fed more frequently on domestic birds. $A$. hyrcanus sinensis fed on domestic mammals and not on chickens. Sasa and associates (94) using baited traps in Tokyo found $C$. pipiens and $C$. tritaeniorhynchus to be the dominant species in 1948, and C. tritaeniorhynchus and Aedes vexans in 1949 using different collection sites. C. tritaeniorhynchus appeared suddenly at the end of July and toward the end of August disappeared rapidly. A. hyrcanus sinensis had a population curve similar to C. tritaeniorhynchus. They found the same feeding preferences as did Sasa \& Sabin. Kitaoka and associates (83) also collected mosquitoes in Tokyo and vicinity during the years 1948 and 1949, chiefly from domestic animal shelters. The four most commonly collected species were $C$. tritaeniorhynchus, $A$. hyrcanus sinensis, $A$. vexans, and $C$. pipiens. From July to September C. tritaeniorhynchus was the predominant mosquito. C. tritaeniorhynchus was the mosquito most frequently collected in domestic animal traps. C. pipiens attacked man more frequently.

Okinawa:- Tigertt \& Hammon (28) have summarized mosquito collections by various investigators on Okinawa in 1945, 1946, 1947, and 1948. C. quinquefasciatus, $C$. tritaeniorhynchus, and $A$. hyrcanus sinensis were the common species found.

Guam:- Reeves \& Rudnick (75) made a survey in Guam in February and March 1948, following an encephalitis epidemic, and again from November 1948 to January 1949. In human dwellings 99 per cent of mosquitoes collected were $C$. quinquefasciatus. In human bait collections at the margins of native villages, $A$. pandani was the dominant mosquito. Using stable-type traps, $A$. pandani, $A$. vexans, $A$. subpictus, $C$. annulirostris, and $C$. quinquefasciatus were the common species collected. It was concluded that $C$. quinquefasciatus, $C$. annulirostris, $A$. vexans, $A$. albopictus, and $A$. pandani should be considered as possible vectors.

Murray Valley encephalitis virus.--Burnet (95) considers that C. annulirostris is almost certainly the principal vector. In the Murray Valley it is a river-bottom mosquito, feeding freely on water birds and rabbits.

Rift Valley fever virus. - In enzootic and epidemic areas Gear et al. (33) found $C$. theileri abundant. Aedes caballus was next in abundance. Both species are nondomestic but do feed on sheep and man. They state that Eretmapodites chrysogaster is not found in the Union of South Africa. Smithburn et al. (84) state that it is improbable that $E$. chrysogaster could propagate in the open country in Kenya where the disease occurred in the past. It is also a daytime feeder, but evidence from Kenya was that a night biting insect was involved.

Yellow fever virus.-Africa:-In Uganda, transmission of yellow fever virus to human beings has been associated with the presence of $A$. simpsoni. Gillett (96) has found that in Uganda there are biting and nonbiting populations of $A$. simpsoni, as far as human beings are concerned. He attributes 
the relative absence of yellow fever antibodies in the human population in Uganda outside of Bwamba to the presence of the nonbiting population. In Ken ya, the lemurs, Galagos crassicaudatus and G. senegalensis, appear to be more important than monkeys in maintaining yellow fever virus. According to Haddow (67) lemurs are active during the night and sleep in nests during the day and do not appear to be good mosquito hosts.

\section{SURVIVAL OF VirUS}

Many writers recently have pointed out the difficulty of accounting for survival of virus during periods unfavorable for mosquitoes. Sabin (74) and Sasa \& Sabin (93) question that the few overwintering adult C. tritaeniorhynchus or $A$. hyrcanus sinensis could maintain the Japanese encephalitis virus in Japan. Galindo et al. (97) point out that during the dry season in Panama all the Haemagogus species virtually disappear together with $A$. leucocelaenus, and they raise the problem of survival during this period. Taylor \& Theiler (98) point out that in southern Brazil it is not known how yellow fever virus survives through the cold season when known mosquito vectors virtually disappear. To Ross \& Gillett (90) it appears that in some small isolated forests in Uganda where the immune proportion of monkeys is high and where the dry season is relatively prolonged, the primate-mosquito cycle does not seem adequate to account for the maintenance of virus. Haddow et al. (66) suggest the possibility that in yellow fever the monkey-to-monkey cycle, like the man-to-man cycle, may be the end point of a chain about which nothing is known at present.

Transovarial transmission.-Japanese encephalitis virus:-During 1941 Mitamura \& Kitaoka (72) could not confirm their previous work indicating transovarial transmission in $C$. pipiens.

Yellow fever virus:-Gillett et al. (99) were unable to obtain any evidence of transovarial transmission in A. africanus.

Carry-over in hibernating mosquitoes.-Japanese encephalitis virus:Hurlbut (100) reported that infected C. quinguefasciatus kept at $8^{\circ}$ to $13^{\circ} \mathrm{C}$. for 82 days to simulate natural hibernation were still capable of transmission. In discussing isolation of virus from mosquitoes, Mitamura et al. (73) emphasize that isolations were obtained only during the second half of July, August, and the first half of September, although collections were made throughout the year.

Western equine and St. Louis encephalitis viruses:-From January 8 to the middle of May 1951, bi-weekly inspections of cellars were made in Scottsbluff County, western Nebraska by Keener (101). The lowest temperature encountered in the cellars was $33^{\circ} \mathrm{F}$. C. tarsalis was found at nearly every visit. The largest number caught at any visit was 15 . Up to March 3, 47 were caught in one cellar, and 24 in another. Eighteen mosquitoes were tested for virus with negative results.

Carry-over in auxiliary cycles involving mites or ticks. - Since viruses of diseases such as louping ill, Russian spring summer encephalitis, and Nairobi 
sheep disease are transmitted by and carried over from one season to the next in ticks, it has long been suggested that a similar mechanism may be found to account for the survival of mosquito-transmitted viruses over unfavorable seasons. Smith and associates (8) reported that St. Louis virus had maintained itself in a Dermanyssus gallinae mite colony for three years and that it was possible to produce viremia in chickens by feeding these mites on them. Mosquitoes feeding on these chickens later were able to transmit St. Louis virus to other chickens. Viremia in all the chickens had to be demonstrated by two serial passages on the chorio-allantoic membrane of chick embryos and then by inoculation of mice. Direct inoculation of mice produced no illness. Mites could not be infected with a California strain of St. Louis virus. As mentioned under transmission studies, other workers have not been able to transmit virus with mites. Rather large numbers of ticks of various species have been examined at the Rocky Mountain Laboratory without isolating any mosquito transmitted virus.

Periodic reintroduction of virus from more favorable areas.-Migrating birds:- The hypothesis that migrating birds transport virus apparently was first presented by Ten Broeck (102) several years ago in connection with his studies of eastern equine encephalomyelitis. It has been stressed recently by Australian workers in connection with their study of Murray Valley encephalitis. Burnet (95) postulates that persistence of virus in nature is confined to tropical or near tropical areas, where mosquitoes capable of transmitting virus are present the year around. Migrating birds then transport the virus through regions in which effective mosquito transmitters are present. Foci of infected mosquitoes are built up which then infect other birds, which, in turn, carry the virus farther and start new foci. No evidence of such spread has yet been presented.

Transportation of infected mosquitoes by air currents. - Haddow et al. (66, in discussing the problem of maintenance of yellow fever virus in small forests and in dry areas, suggests the possibility that infected mosquitoes are introduced periodically from favorable areas by convection currents and winds.

Other mechanisms.--Sasa \& Sabin (93) mention the possibility that an in testinal parasite or other parasite of domestic animals maintains the virus by transmission from one generation to the next. Foster \& Shahan (103) could not isolate virus from parasites collected from moribund horses following experimental acute encephalitis (whether eastern or western not stated). Findlay and Howard (104) were able to demonstrate the presence of Rift Valley fever virus in the larvae of Taenia crassicolis removed from the liver of mice inoculated with this virus.

\section{VIRUS RELATIONSHIPS}

Serological relationships have been pointed out among members of the mosquito-transmitted viruses. Such relationships are of interest because they may indicate a common origin and similarities in ecology. 
California virus.- Hammon et al. (87) found that St. Louis and Japanese encephalitis virus antigens showed slight fixation in the presence of California virus immune serum.

Murray Valley virus. - French (105), Miles \& Howes (55), and Pond et al. (106), using the complement-fixation and neutralization tests, found the Murray Valley virus related to the Japanese, St. Louis, and West Nile viruses, with closest relationship to the Japanese virus.

Japanese virus group and dengue and yellowfever viruses.-With the use of hyperimmune sera against dengue virus, yellow fever virus, and Japanese encephalitis virus, and the complement-fixation test, Sabin (107) was able to show that there was a common antigen present in low titer in the dengue, yellow fever, Japanese, and West Nile viruses. He showed interference between yellow fever virus and dengue virus in human volunteers, and, jointly with Theiler, in rhesus monkeys and Aedes aegypti $(108,109)$. The relationship between dengue and yellow fever viruses and members of the St. LouisJapanese group may possibly point to a common origin. The significance of the serological relationship of the West Nile virus to these viruses is not clear because so little is known of its natural history.

Other relationships. - Smith burn (110) did cross-neutralization tests with the nine viruses isolated by yellow fever workers in Africa and South America from mosquitoes, and with the well-known mosquito and tick transmitted viruses. He found many antisera neutralizing heterologous viruses; such neutralization was generally unilateral and only slight in amount. At present the interrelations found by Smithburn do not make an understandable pattern, but they do suggest that arthropod transmitted viruses may be shown to fall into definite groups.

\section{Newly Described Viruses}

Ntaya virus was isolated by Smithburn \& Haddow (111) in February 1943 in Uganda by the inoculation of mice with a suspension of 1318 mosquitoes, consisting of approximately 24 species, with Culex species predominating. No antibodies were found in the sera of 43 people living near the N taya swamp where the mosquitoes were collected. Zika virus was isolated by Dick et al. (112) in mice by the inoculation of a suspension of $86 \mathrm{~A}$. africanus collected in the Zika Forest, Uganda, and, in April, 1947, from the blood of a sentinel monkey. Antibodies were found in 4 of 71 people living in Uganda. Uganda S. virus was isolated by Dick \& Haddow (113) from a lot of 65 mosquitoes consisting of three Aedes species, predominantly A. longipalpis, by the inoculation of mice. Antibodies were found in 5.8 per cent of 121 sera from Uganda residents and in 1 of 9 monkey sera. Smithburn (114) used these three viruses and five other African viruses in neutralization tests with 297 sera from residents of Uganda and Tanganyika. 14.5 per cent neutralized the Ntaya virus, 12.8 per cent the Zika virus, and 7.7 per cent the Uganda S. virus. It appeared that a person who acquired immunity to either N taya, Zika, Uganda S., or West Nile virus had a much greater than normal 
chance of acquiring immunity to another of this group, indicating, perhaps, transmission by similar vectors. During the past decade five new viruses have been isolated from mosquitoes in Africa and four in South America by yellow fever workers (:110). Their isolation is of great significance in emphasizing the importance of arthropods in the dissemination of viruses.

\section{An Estimate of Progress}

The large amount of study devoted to these viruses has yielded meager results as measured by the establishment of specific mosquito-vertebrate cycles.

It was established relatively quickly and easily that the cyclic passage of yellow fever and dengue viruses between man and certain domestic mosquito species was a very efficient mechanism for maintaining these viruses. When in the study of yellow fever it became necessary to search for virus cycles among wild animal populations the difficulties of study were increased greatly because of the number of animal species that had to be investigated. In vestigators with very different scientific backgrounds, working cooperatively, were necessary to establish the cyclic transfer of virus between certain tree hole breeding mosquitoes and primates.

Other mosquito transmitted viruses have been studied much less intensively. Only in the case of the western equine virus is a mosquito-vertebrate cycle adequately established. Here a bird-Culex tarsalis cycle appears to be important. Evidence for this cycle in the case of the St. Louis virus is less convincing. In Japan the importance of $C$. tritaeniorhynchus in disseminating the Japanese virus is indicated by the isolation of virus from this species, positive transmission experiments, good correlation of peak mosquito population with the occurrence of human disease, and by its feeding habits. The vertebrate part of the cycle has not been established. Although man and domestic animals have a high incidence of antibodies, it is not known whether they are at the end of a cycle or are part of a continuous virus cycle. With the remainder of the viruses in this group the existence of mosquito cycles is indicated chiefly by the epidemiological pattern of the disease caused by the virus, or by the isolation of virus from mosquitoes, or by both criteria.

With respect to all of the viruses which occur in the temperate zones, evidence of the presence of virus has been obtained only during a few summer months. The real or apparent absence of virus for most of the year has led to speculation concerning other mechanisms for its maintenance during this period. Although many alternative mechanisms to the mosquito-vertebrate cycle have been proposed, none can be considered as having been established. The conditions under which a mosquito-vertebrate cycle fails to account for the maintenance of virus must be much better understood before there can be an in telligent search for another mechanism. Present knowledge of the mosquito-vertebrate cycle does not even permit a definite statement that an alternative cycle is necessary. 
Studies to date are quite adequate to demonstrate the importance of mosquitoes in disseminating virus.

\section{LITERATURE CITED}

1. Van Rooyen, C. E., and Rhodes, A. S., Virus Diseases of Man (Thomas Nelson \& Sons, New York, N. Y., 1202 pp., 1948)

2. Strode, G. K., Yellow Fever (McGraw-Hill Book Co., Inc., New York, N. Y., 710 pp., 1951)

3. Ayres, J. C., and Feemster, R. F., New Engl. J. Med., 240, 966-75 (1949)

4. Hammon, W. McD., and Reeves, W. C., Calif. Med., 77, 303-9 (1952)

5. Lennette, E. H., and Longshore, W. A., Calif. Med., 75, 189-95 (1951)

6. Infectious Encephalitis, Reported Human Cases, Laboratory Confirmations, and Reported Cases in Horses, Calif. State Dept. Public Health, Weekly Bulletin, Processed (Nov. 7, 1952)

7. Mulder, D. W., Diseases of Nervous System, 12, 259-64 (1951)

8. Smith, M. G., Blattner, R. J., Heys, F. M., and Miller, A., J. Exptl. Med., 87, 119-38 (1948)

9. Fulton, J. S., and Burton, A. N., Can. J. Public Health, 43, 212-20 (1952)

10. Gareau, U. J., Pediatrics, 3, 777-82 (1949)

11. Dravin, I., Coffey, J. H., and Dine, W. C., Ann. Internal Med., 34, 705-11 (1951)

12. Reeves, W. C., Hammon, W. McD., Lazarus, A. S., Brookman, B., Mclure, H. E., and Dretschman, W. H., J. Infectious Diseases, 90, 291-301 (1952)

13. Saphir, W., and Milzer, A., J. Am. Med. Assoc., 140, 778-80 (1949)

14. Sanders, M., Soret, M. G., and Akin, B. A., Bact. Proc., 52nd meeting, 83-84 (1952)

15. Milner, K. C., Kelley, G. P., and Shaffer, M. F., New Orleans Med. Surg. J., 100, 270-73 (1947)

16. Hauser, G. H., New Orleans Med. Surg. J., 100, 551-58 (1948)

17. Eklund, C. M., Brennan, J. M., and Bell, J. F., Bull. Pan-Amer. Sanit. Bur., 29, 493-507 (1950)

18. Levi-Castillo, R., Acta Tropica, 9, 77-80 (1952)

19. Chao, P., and Chung, H., Chinese Med. J., 69, 522-60 (1951)

20. Hammon, W. McD., Proc. 4th Intern. Congr. Trop. Med. Malaria, 568-75 (Washington, D. C., May, 1948)

21. Wyatt, N. F., J. Lab. Clin. Med., 34, 1656-70 (1949)

22. Hullinghorst, R. L., Burns, K. F., Choi, Y. T., and Whatley, L. R., J. Am. Med. Assoc., 145, 460-66 (1951)

23. Lincoln, A. F., and Sivertson, S. E., J. Am. Med. Assoc., 150, 268-73 (1952)

24. Dickerson, R. B., Newton, J. R., and Hansen, J. E., Am. J. Medicine, 12, 277-88 (1952)

25. Paterson, P. Y., Smadel, C. L., Wisseman, C. R., Jr., Ley, H. L., Jr., and Diercks, F. H., Am. J. Hyg., 56, 320-30 (1952)

26. Hale, J. H., Lim, K. A., and Chee, P. H., Ann. Trop. Med. Parasitol., 46, 220-26 (1952)

27. Mitamura, T., Kitaoka, M., and Miura, T., Japan Med. J., 3, 257-64 (1950)

28. Tigertt, W. D., and Hammon, W. McD., Am. J. Trop. Med., 30, 689-722 (1950)

29. Salafranca, E. S., and Espiritu, L., Am. J. Trop. Med., 29, 219-27 (1949)

30. Anderson, S. G., Med. J. A ustralia, I, 97-100 (1952) 
31. Miles, J. A. R., Fowler, M. C., and Howes, D. W., Med. J. Australia, I, 799-800 (1951)

32. Derrick, E. H., Med. J. Australia, II, 582-84 (1952)

33. Joubert, J. D. S., Ferguson, A. L., and Gear, J., S. African Med. J., 25, 890-91 (1951)

34. Gear, J., de Meillon, B., Meassach, V., and Davis, D. H. S., S. African Med. J., 25, 908-12 (1951)

35. Mundel, B., and Gear, S., S. African Med. J., 25, 787-800 (1951)

36. Henning, M. W., J. S. African Vet. Med. Assoc., 23, 65-78 (1952)

37. Elton, N. W., Am. J. Trop. Med. Hyg., 1, 436-56 (1952)

38. Castillo, G., Yellow Fever (Presented at 1st Inter-American Congr. Public Health, Havana, Cuba, September 26-October 1, 1952)

39. Kumm, H. W., Am. J. Trop. Med. Hyg., 1, 210-19 (1952)

40. Report on Infectious Equine Encephalomyelitis in the United States in 1949 and 1947, Bureau of Animal Industry, Washington, D. C.

41. Oglesley, W. T., J. Am. Vet. Med. Assoc., 113, 267-70 (1948)

42. Beadle, L. D., Mosqiaito News, 12, 102-7 (1952)

43. Beaudette, F. R., Black, J. J., Hudson, C. B., and Bevins, J. A., J. Am. Vet. Med. Assoc., 121, 478-83 (1952)

44. Livesay, H. R., J. Infectious Diseases, 84, 306-9 (1949)

45. Okubi, K., Sato, K., and Ichikawa, Y., Japan Medical J., 1, 126-32 (1948)

46. Burns, K. F., and Matumoto, M., J. Am. Vet. Med. Assoc., 115, 167-70 (1949)

47. Burns, K. F., Proc. Soc. Exptl. Biol. Med., 75, 621-25 (1950)

48. Hosaya, H., Matumoto, M., and Iwasa, S., Japan. J. Exptl. Med., 20, 587-95 (1950)

49. Tsubaki, S., Masu, S., Obata, Y., and Shimada, F., Kitasato Arch. Exptl. Med., 23, 9-12 (1950)

50. Howitt, B. F., Bishop, L. K., Gorrie, R. H., Kissling, R. E., Hauser, G. H., and Trueting, W. L., Proc. Soc. Exptl. Biol. Med., 68, 70-72 (1948)

51. Bowell, M. B., Deuel, R. E., Jr., Matumoto, M., and Sabin, A. B., Am. J. Hyg., 51, 1-12 (1950)

52. Deuel, R. E., Jr., Bowell, M. B., Matumoto, M., and Sabin, A. B., Am. J. Hyg., 51, 13-20 (1950)

53. Anderson, S. G., Donnelley, M., Stevenson, W. J., Caldwell, N. J., and Eagle, M., Med. J. Australia, I, 110-14 (1952)

54. Anderson, S. G., Med. J. Australia, II, 582-84 (1952)

55. Miles, J. A. R., and Howes, D. W., Australian J. Exptl. Biol. Med. Sci., 30, 352-62 (1952)

56. Smithburn, K. C., Haddow, A. J., and Gillett, J. D., Brit. J. Exptl. Pathol., 29, 107-20 (1948)

57. Howitt, B. F., Dodgre, H. R., Bishop, L. K., and Gorrie, R. H., Proc. Soc. Exptl. Biol. Med., 68, 622-25 (1948)

58. Mace, D. L., Ott, R. L., and Cortez, F. S., Bull. U. S. Army Med. Dept., 9, 504-7 (1949)

59. Hutson, G. A., Howitt, B. F., and Cockburn, T. A., Proc. Soc. Exptl. Biol. Med., 78, 290-93 (1950)

60. Sooter, C. A., Howitt, B. F., Gorrie, R., Proc. Soc. Exptl. Biol. Med., 79, 507-9 (1952)

61. Burns, K. F., and Matumoto, M., Am. J. Vet. Research, 10, 146-49 (1949) 
62. Hammon, W. McD., Reeves, W. C., and Sather, G. E., Am. J. Hyg., 53, 249-61 (1951)

63. Clark, H. C., Am. J. Trop. Med. Hyg., 1, 78-86 (1952)

64. de Rodaniche, E. C., Am. J. Trop. Med. Hyg., 1, 789-95 (1952)

65. Dick, G. W. A., Trans. Roy. Soc. Trop. Med. Hyg., 46, 47-48 (1952)

66. Haddow, A. J., Dick, G. W. A., Lumsden, W. H. R., and Smithburn, K. C., Trans. Roy. Soc. Trop. Med. Hyg., 45, 189-224 (1951)

67. Haddow, A. J., Ann. Trop. Med. Parasitol., 46, 135-43 (1952)

68. Chamberlain, R. W., Rubin, H., Kissling, R. E., and Eidson, M. E., Proc. Soc. Exptl. Biol. Med., 77, 396-97 (1951)

69. Howitt, B. F., Dodge, H. R., Bishop, L. K., and Gorrie, R. H., Science, 110, 141-42 (1949)

70. Thompson, G. A., Howitt, B. F., Gorrie, R., and Cockburn, T. A., Proc. Soc. Exptl. Biol.' Med., 78, 289-90 (1951)

71. Hammon, W. McD., Tigertt, W. D., Sather, G. E., and Schenker, H., Am. J. Hyg., 50, 51-56 (1949)

72. Mitamura, T., and Kitaoka, M., Japan Med. J., 3, 141-48 (1950)

73. Mitamura, T., Kitaoka, M., and Imai, M., Japan. Med. J., 3, 149-59 (1950)

74. Sabin, A. B., Am. J. Hyg., 51, 36-62 (1950)

75. Reeves, W. C., and Rudnick, A., Am. J. Trop. Med., 31, 633-58 (1951)

76. Hammon, W. McD., Reeves, W. C., and Sather, G. E., J. Immunol., 67, 35767 (1951)

77. Miles, V. I., Howitt, B. F., Gorrie, R. H., and Cockburn, T. A., Proc. Soc. Exptl. Biol. Med., 77, 395-96 (1951)

78. Kissling, R. E., Rubin, H., Chamberlain, R. W., and Eidson, M. E., Proc. Soc. Exptl. Biol. Med., 77, 398-99 (1951)

79. Sooter, C. A., Howitt, B. F., Gorrie, R. H., and Cockburn, 'T. A., Proc. Soc. Exptl. Biol. Med., 77, 393-94 (1951)

80. Reeves, W. C., and Hammon, W. McD., J. Immunol., 69, 511-14 (1952)

81. Hammon, W. McD., Rees, D. M., Casals, J., and Meiklejohn, G., Am. J. Hyg., 50, 46-50 (1949)

82. Hurlbut, H. S., and Thomas, J. I., Am. J. Trop. Med., 29, 215-17 (1949)

83. Kitaoka, M., Miura, T., and Ogata, T., Japan. Med. J., 3, 331-47 (1950)

84. Smithburn, K. C., Haddow, A. J., and Lumsden, W. H. R., Brit. J. Exptl. Pathol., 30, 34-47 (1949)

85. Reeves, W. C., Am. J. Public Health, 41, 678-86 (1951)

86. Smith, M. G., Blattner, R. J., and Heys, F. M., J. Exptl. Med., 86, 229-37 (1947)

87. Hammon, W. McD., Reeves, W. C., and Sather, G. E., J. Immunol., 69, 493510 (1952)

88. Miles, J. A. R., Australian J. Exptl. Biol. Med. Sci., 30, 341-51 (1952)

89. Smithburn, K. C., Mahaffy, A. F., Haddow, A. J., Kitchen, S. F., and Smith, J. F., J. Immunol., 62, 213-27 (1949)

90. Ross, R. W., and Gillett, J. D., Ann. Trop. Med. Parasitol., 44, 351-56 (1950)

91. Hurlbut, H. S., and Thomas, J. I., Am. J. Trop. Med., 30, 682-88 (1950)

92. Jenkins, D. W., Am. J. Trop. Med., 30, 909-16 (1950)

93. Sasa, M., and Sabin, A. B., Am. J. Hyg., 51, 21-35 (1950)

94. Sasa, M., Kano, R., Hayashi, S., Kimura, M., Miura, A., Oyama, K., Sato, K., Hosoya, H., and Hasegawa, K., Japan. J. Exptl. Med., 20, 509-17 (1950) 
95. Burnet, F. M., Am. J. Public Health, 42, 1519-21 (1952)

96. Gillett, J. D., Ann. Trop. Med. Parasitol., 45, 110-21 (1951)

97. Galindo, P., Trapido, H., and Carpenter, S. J., Am. J. Trop. Med., 30, 533-74 (1950)

98. Taylor, R. M., and Theiler, M., Proc. 4th Intern. Congr. Trop. Med. Malaria, 506-15 (Washington, D. C., May, 1948)

99. Gillett, J. D., Ross, R. W., Dick, G. W. A., Haddow, A. J., and Hewett, L. E., Ann. Trop. Med. Parasitol., 44, 342-50 (1950)

100. Hurlbut, H. E., Am. J. Hyg., 51, 265-68 (1950)

101. Keener, G. G., Mosquito News, 12, 205-9 (1952)

102. Ten Broeck, C., Intern. Congr. Microbiol. Rept. Proc., 300-1 (3rd Congr., New York, N. Y., 1939)

103. Foster, A. O., and Shahan, M. S., Proc. Helminthol. Soc. Wash., D. C., 9, 20-21 (1942)

104. Findlay, G. M., and Howard, C. M., Arch. ges. Virusforsch., 4, 411-32 (1951)

105. French, E. L., Med. J. Australia, I, 100-3 (1952)

106. Pond, W. L., Rogers, N. G., and Russ, S. B., Soc. Am. Bacteriologists Proc., 52nd meeting, 84-85 (Baltimore, Md., 1952)

107. Sabin, A. B., Federation Proc., 8, 410 (1949)

108. Sabin, A. B., Bact. Rev., 14, 225-32 (1950)

109. Sabin, A. B., Am. J. Trop. Med. Hyg., 1, 30-50 (1952)

110. Smithburn, K. C., J. Immunol., 68, 441-60 (1952)

111. Smithburn, K. C., and Haddow, A. J., Proc. Soc. Exptl. Biol. Med., 77, 130-33 (1951)

112. Dick, G. W. A., Kitchen, S. F., and Haddow, A. J., Trans. Roy. Soc. Trop. Med. Hyg., 46, 509-20 (1952)

113. Dick, G. W. A., and Haddow, A. J., Trans. Roy. Soc. Trop. Med. Hyg., 46, 600-18 (1952)

114. Smithburn, K. C., J. Immunol., 69, 223-25 (1952) 